\title{
Active and Passive Adaptation of Floating Houses (Rumah Lanting) to the Tides of the Melawi River in West Kalimantan, Indonesia
}

\author{
Jawas Dwijo Putro ${ }^{A^{*}}$, Zairin Zain ${ }^{\mathrm{A}}$ \\ Received: January 19, 2021 | Revised: May 07, 2021 | Accepted: May 21, 2021 \\ doi: 10.5937/gp25-30422
}

\begin{abstract}
Floating houses or Rumah Lanting are one of the settlement cultures found in most river streams in Kalimantan and are observed to be different from several other houses in the area. They are mitigationproof houses designed to respond to the risk of disasters usually experienced in the traditional settlements of West Kalimantan. Their structures have the ability to adapt to environmental conditions including natural disasters such as the river tides routinely experienced as a flood during the rainy season and as ebb in the dry season.

This study aimed to identify the human-adaptation process existing in these floating houses through direct observation for two years during the dry and rainy seasons as well as in-depth interviews conducted with occupants of these buildings. The adaptation processes identified include the active and passive adaptation of the dwellers. The active aspect was observed from the behavior of occupants in accommodating the occurrence of disaster in the surrounding environment while the passive was identified as the physical changes implemented in the building to mitigate the disaster. The focus of this research was on some dwellings on the river banks settlement in the Melawi River near Sintang Regency of West Kalimantan Province and a qualitative approach with a case study was implemented. The samples were determined through a non-probability approach in the form of a purposive sampling method based on certain selected criteria which included the previous experience of ebb and flow of river water in the Rumah Lanting.

The results showed the existence of active and passive adaptations for the dwellers of the floating houses in West Kalimantan. The active aspect observed involves the behavior of the occupants in adapting to natural disasters with the focus on the changes in the activity patterns, territory, and privacy. Meanwhile, the passive aspect showed some modifications in the architectural elements of the building such as the position, orientation, access, and function.
\end{abstract}

Keywords: Floating House; Active Adaptation; Passive Adaptation

\footnotetext{
A Universitas Tanjungpura, Faculty of Engineering, Department of Architecture, Pontianak 78124, Kalimantan Barat, Indonesia; jawasdwijo@teknik.untan.ac.id; zairin.zain@untan.ac.id

* Corresponding Author: Jawas Dwijo Putro; e-mail: jawasdwijo@teknik.untan.ac.id
} 
Indonesia is a country with cultural diversity spreading throughout the Archipelago as observed with each region having different culture according to its characteristics. One of the manifestations of this is the settlement practice which involves living on the ground and water towards adapting to environmental conditions. This is necessary because nature is always changing and people need to adapt to climate change. Moreover, the settlements in some areas are developed due to the influence of natural reserves, geography, and the supporting capacity of environmental ecology (Clark, 2009). This is associated with the concept of settlement formation which is defined as a process involving ecological elements such as climate, water sources, sunlight, and soil (Marpaung \& Senders, 2020). The culture of the locals in a settlement is also usually influenced by the economic, social, and cultural factors of the inhabitants. Furthermore, the spatial characteristics of settlements have been described in a previous study as the relation of the environment with the community's socio-economic conditions (Reinmann et al., 2016).

The settlement culture of Kalimantan is closely related to the natural environment and socio-economic conditions of the local community. The geographical condition with extensive forests and large rivers also influences the settlement cultures of the people with some living in the forest while others chose to live on the large rivers. Historically, the people living on the river are migrants aiming to conduct some economic activities such as trading, storage of goods, etc at the past arrival-time. These riverside settlements are, however, one of the factors initiating regional development in several regions of the city.

The development of these riverbanks as settlements is a consequence of the interaction between migrants and indigenous people as well as the high intensity of their activities. This gradual interaction led to the participation of these migrants in the improvement of the economic conditions of local communities which are geographically located in the interior areas without accessibility and infrastructure. These problems change the orientation of the settlements towards the river (Mentayani, 2016).

A floating house structure is one of the settlement cultures in Kalimantan and it involves the residence of local people by the side of a river. These houses are usually constructed with local materials and are still available in several major rivers in West Kalimantan. They exist as dwellings in the Melawi River which is one of the major rivers in the area. It is important to note that riverside settlement is a culture with a sys- tem of values, rules, and norms. Moreover, the local wisdom and culture of the people living in the established settlements of a particular area are usually the character of the surviving cultural identity on the riverside (Wicaksono, 2018). Individual efforts to preserve local wisdom also usually affect the sustainability of a community's cultural identity (Pesurnay, 2018).

The scholars in some publications identified the two main reasons people live in a floating house to include history and life necessities. Historically, the floating house is a general dwelling structure for people from outside villages to temporarily stay till the completion of their interaction and economic activities with the indigenous community. In terms of life necessities, the occupants are people without property rights on the mainland that build structures on the river as a place to live (Mustansyir, 2013).

The main problem for the floating house occupants is the limitation of space for activities. This affects their movements and also requires effective utilization of particular existent rooms. The traditional design of the structure also has particular spaces for different activities and the absence of insufficient space to accommodate these activities has the ability to cause conflicts among the dwellers. There is, therefore, the need for adaptations and changes in the living pattern of the house with respect to the environmental conditions. This is important because an efficient arrangement and multi-purpose functionalization of limited space can affect productivity and minimize conflicts (Guo, 2002). This adjustment is usually continuous and has become the habit of the occupants such that they eventually become comfortable while conducting their activities in the building. Moreover, space is continuously provided in line with the daily activities of the owner in order to mitigate the limitations of the floating house (Estaji, 2017).

The process of adaptation by the occupants occurs internally with the focus on the space and activities and externally which involves a creative interaction between the occupants and the environment (Priemus, 1986). The external adaptation process is a measure of the occupants' ability to adapt to the building's conditions and the environment. In several areas of Kalimantan, the floating house is an example of a structure designed to respond to changes in the environmental conditions due to disaster such as a flood during the rainy season and aridity in the dry season. These conditions also occur in the Melawi River with the water level usually rising and reducing significantly due to climate change. The river water level normally rises during the rainy season, thereby, causing the 
flood to reach settlements on the land with a height of 1-2 meters while the riverbed is usually visible by leaving 2-5 meters of water surface to river stream width during the dry season. This, therefore, requires some level of adaptation from the occupants of the floating house. This has been the norm for a very long time and has become a habit for the occupants to achieve a comfortable living while performing their daily activities.

This study, therefore, aimed to identify the occupants' adaptation process and activities within a floating house. This involved the observation of the activities of the occupants inside the floating houses during the river's particular disaster in the form of flood and ebb for 2 years using Melawi River in the Sintang Regency of West Kalimantan as the case study.

The purpose of this study was to recognize the adjustment process autonomously implemented by the occupants towards river tides disasters and the physical changes usually made in the floating houses. This is necessary because, according to Riyandari (2018), the direction of the disaster management process in the riverbank settlements has always been focused on prevention through the involvement of the local governments. It is, therefore, possible for stakeholders to prevent flooding in riverbank settlements by issuing appropriate policies on disaster prevention efforts such as the construction of early warning systems or the development of a natural disaster mitigation layout for dwellings in these settlements.

\section{Melawi River Characteristics}

Melawi River is a tributary of the Kapuas River in West Kalimantan. It stretches from Sintang Regency to Ambalau Sub-District which is located at its upstream. The length of this river is approximately 600 $\mathrm{km}$ with a depth of approximately 12-16 meters to the riverbed. It currently functions as the economic and transportation lifeblood of the interior communities in West Kalimantan, especially the upstream areas. The Melawi River has experienced regular extreme tides such that it becomes shallow in the dry season, thereby, making it difficult for water transportation routes. Meanwhile, it overflows in the rainy sea-
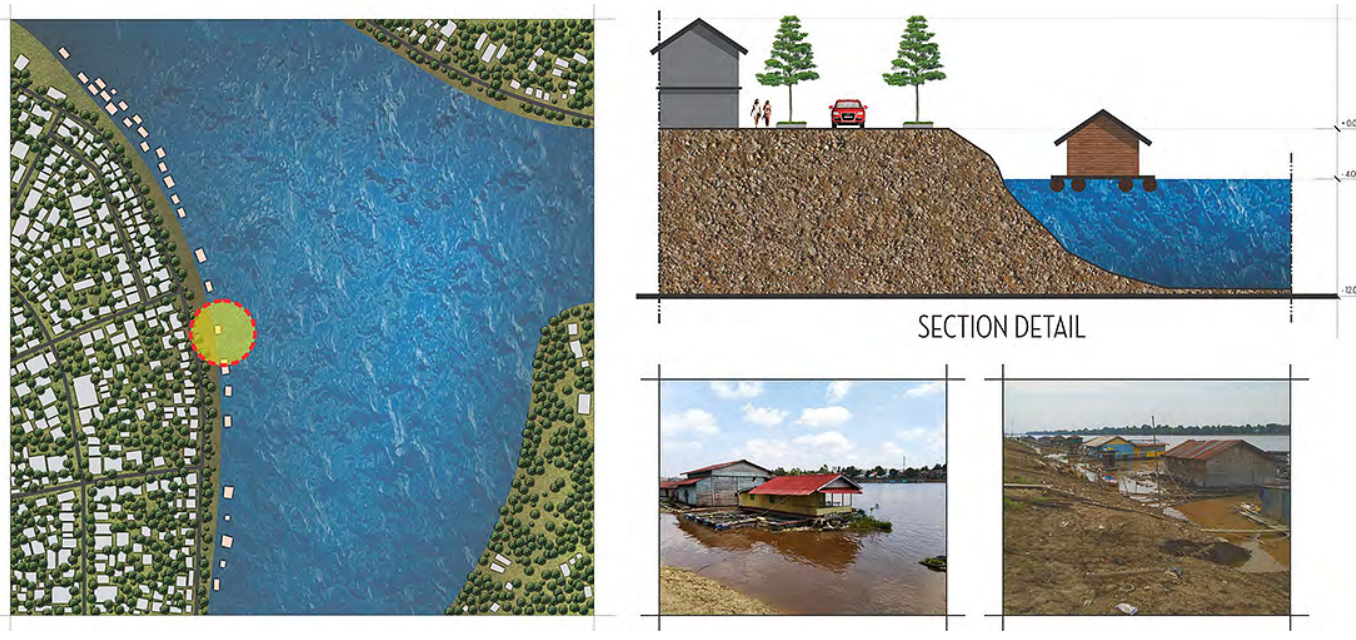

Figure 1. Normal condition of Melawi River
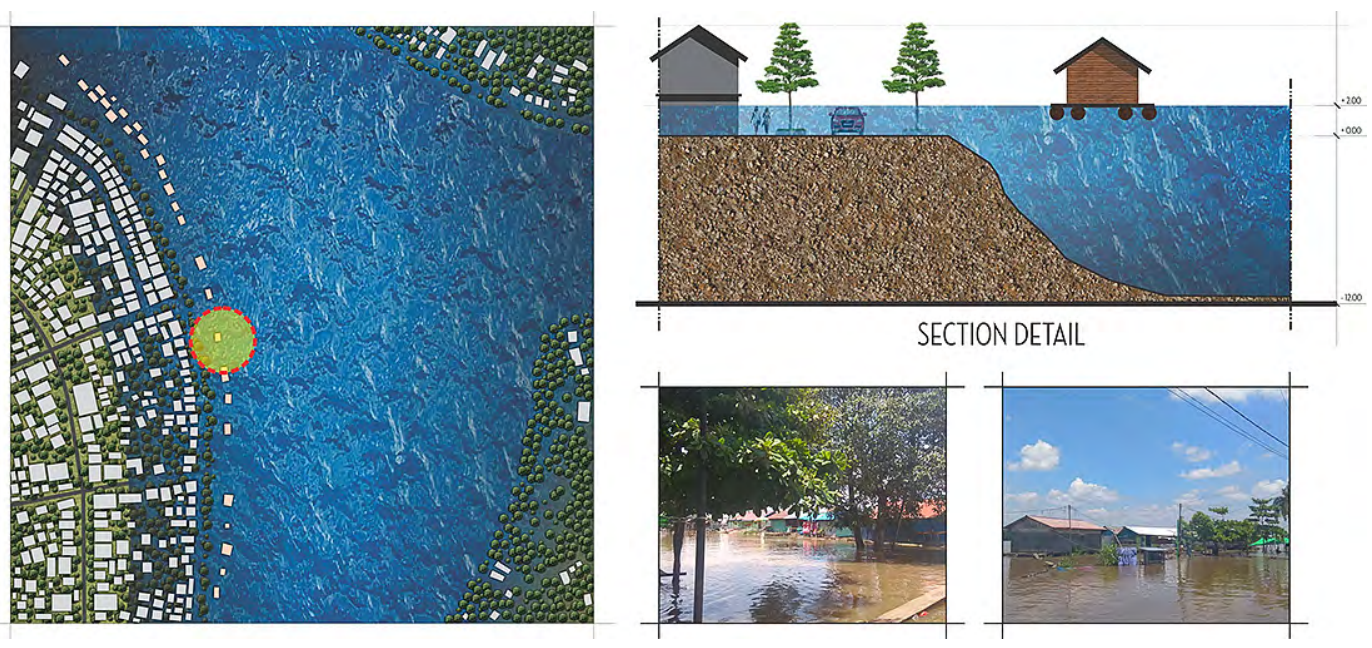

Figure 2. Flood condition of Melawi River 

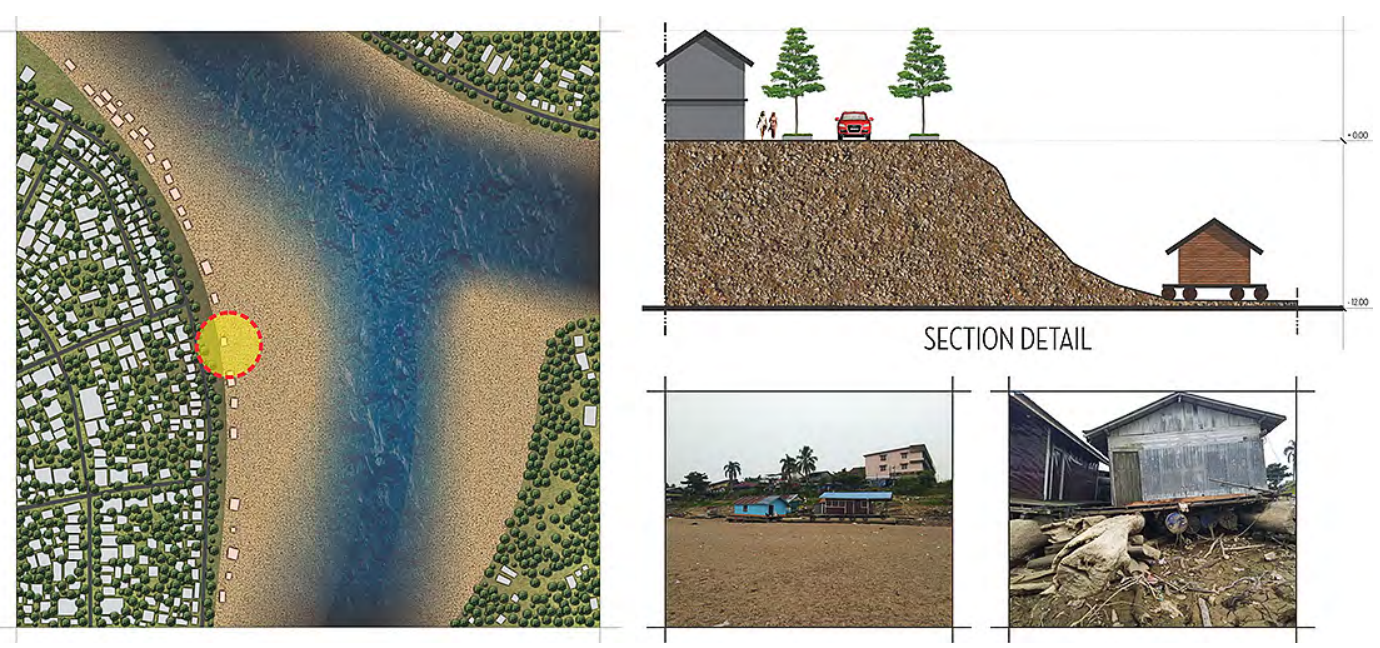

Figure 3. Ebb condition of Melawi River

son and this causes flooding with a height of up to 2 meters in the inland settlement.

Several floating houses on its riverbank are regularly affected by these tides starting from the time the occupants began the settlement. It has, therefore, become a traditional practice for them to respond to this environmental condition.

\section{Literature Review}

\section{Floating House}

The floating house is a unique phenomenon usually found in riverside areas. Its uniqueness lies not only in its shape but also in the daily life patterns of the occupants. It is usually made of wood such as Meranti, Bengkirai, or Belian (Mustansyir, 2013) and a built-construction on the water. The design of this house is a flexible structure due to its ability to adjust its level to the changes in the river's tides (Afdholy, 2017). It is considered a cultural asset for the riverside community and has been reported to be advantageous by being an erosion barrier and river fluctuation controller (Daryanto, 2004).

Rumah Lanting is generally a house made of wood and serves as local wisdom for riverside communities. It is responsive to the environment due to climate change, disasters, and other internal and external factors. The floating houses in West Kalimantan are spread along major rivers such as the Kapuas, Mela$\mathrm{wi}$, and other rivers where they experience tides which makes them follow the water level.

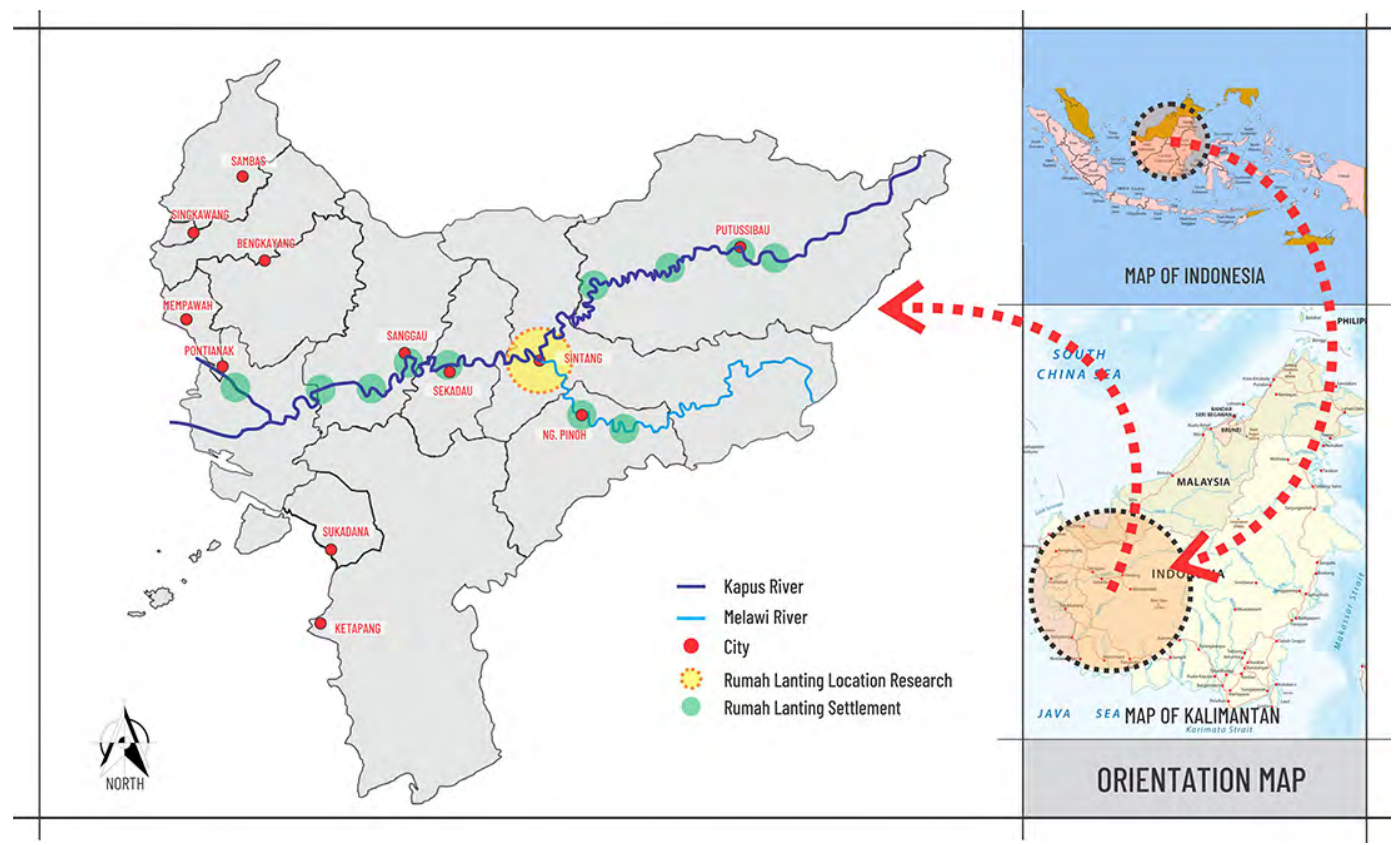

Figure 4. Map of distribution of Rumah Lanting on the Kapuas and Melawi Rivers in West Kalimantan 


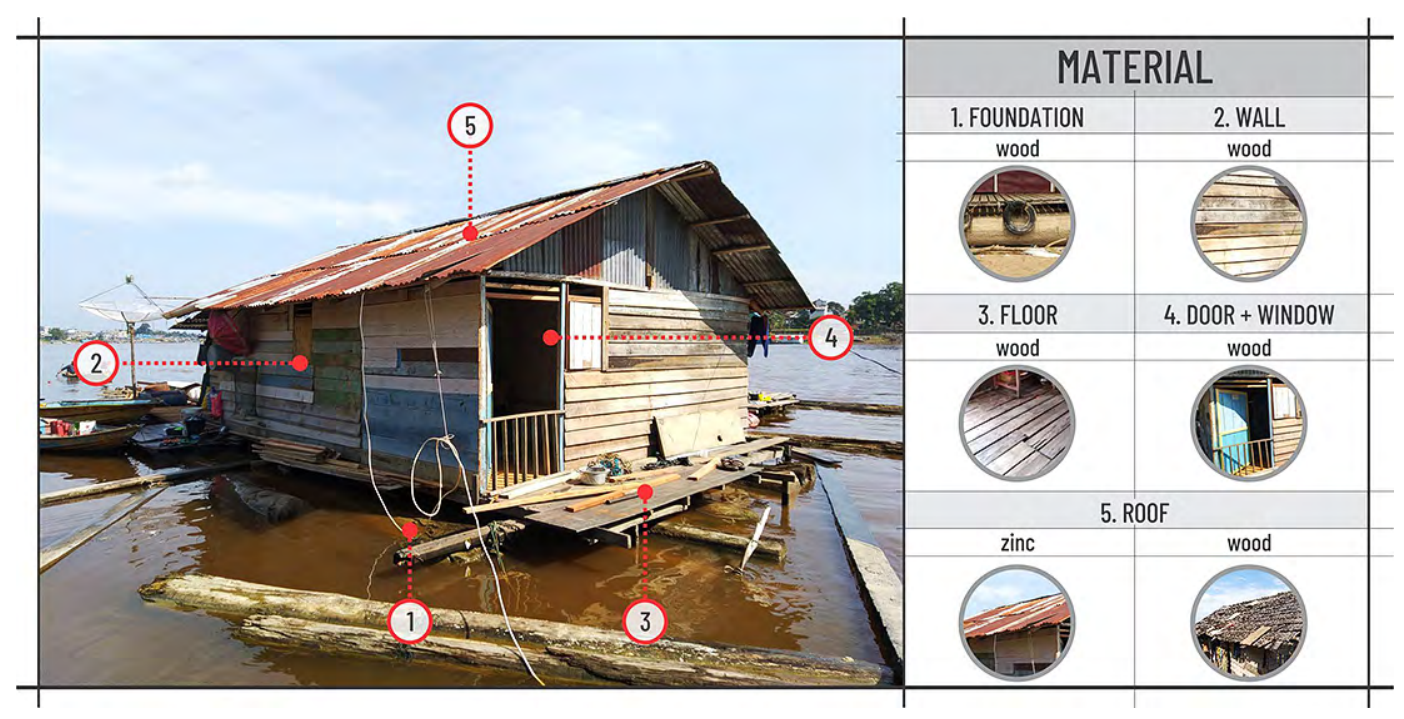

Figure 5. Materials of Rumah Lanting

\section{Adaptation}

Adaptation is an individual's ability to adapt to a certain environment through a behavioral process established on psychological factors in anticipation of future issues (Gifford, 2012). It is also defined as people's effort to adapt to the past and unpredictable disasters. The concept is also described as the ability of individuals to adapt to their environment which usually has physiological, morphological, and cultural effects. The process, however, involves the application of technology and social institutions (Soemarwoto, 1991) in adapting to climate change phenomena causing natural disasters in the surrounding environment (Hilmanto, 2010).

Adaptation is an indicator of an individual's capacity and ability to withstand hazards including those caused by changes in natural conditions. Humans with adequate competence and capability in disaster management survive while those with moderate levels are vulnerable to be victims of disasters. Some of the external factors influencing the individual level of vulnerability to disasters emerge in the form of pressure and shocks from outside while the internal ones involve using resources to cope with disasters (Chambers, 2006). This means individuals adapt to environmental conditions through the employment of all survival aspects in all their activities. There are, however, two types of the adaptation process and they include passive and active processes. The passive process involves changing an individual's particular activities according to environmental conditions while the active aspect means changing the environment's physical elements according to an individual's desires (Gerungan, 1991).

\section{Method}

This research was conducted using the qualitative method and this involves understanding certain phenomena in research subjects by considering their behavior, perceptions, motivation, actions, and other activities as an integrated behavior. Moreover, some of the descriptions were made using words or language (Moleong, 2005) and the procedures for the implementation of this method are flexible according to needs and based on field situations and conditions (Danim \& Darwis, 2003). A case study approach was employed in this study and this is an in-depth analysis of a system which is the same across different cases. This means all the cases are integrated and interconnected as part of the research process (Merriam \& Tisdell, 2016).

The floating houses selected as the object of research were those that have experienced ebb and river water flow. It is important to note that these buildings are designed to withstand disasters (Sihombing, 2019) or respond to natural disasters without changing or adding any physical element to the building. The condition of the floating structures is different from others built on the riverbank which requires adding some properties to bear the occurrence of disasters (Gultom, 2018).

Several floating houses positioned alongside the Melawi River in Sintang Regency of West Kalimantan Province were used in this research with the samples selected using a non-probability approach through purposive sampling based on certain predetermined criteria. This technique was applied due to its ability to determine research samples with specific attention to obtaining more representative data (Sugiyono, 


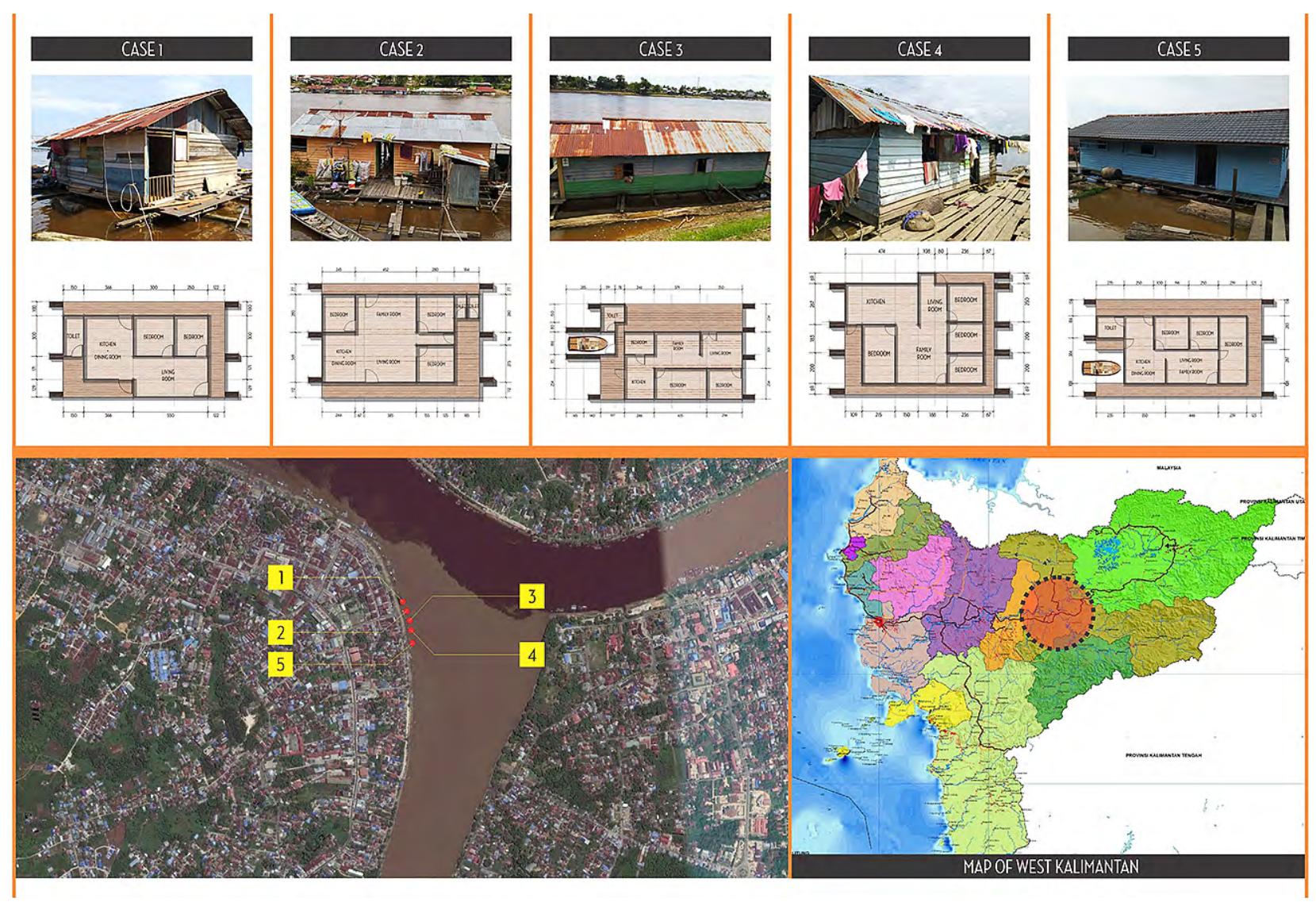

Figure 6. Location and research objects

2012). The selection criteria include the floating houses which is a unit with physical elements adapted to the river's environmental conditions due to climate change and those with certain elements changed as a response towards adapting to environmental conditions such as flood and ebb.

This study aimed to identify the adaptations routinely experienced in the floating houses due to changes in environmental conditions such as a flood during the rainy season and ebb in the dry season. The variables used were active and passive adaptations with the active aspect analyzed by focusing on the changes in the occupants' behavior in response to the changes in the environmental conditions at the time of disaster while the passive involved determining the changes in the physical aspect of the floating house due to changes in the environmental conditions.

\section{Findings and Discussion}

\section{Occupant Characteristics}

The occupants were discovered to have lived in a floating house for at least 5 years, 12 years on average, and the longest was 20 years. Most of the occupants are second consecutive generation while the rest are new people that bought the structure from previous owners. Moreover, the physical condition of the floating houses has not changed significantly since they first occupied it with the only modifications focused on repairs due to damaged elements such as roofs, floors, and walls. It was discovered that the length of time they have lived in the structure affects their ability to adapt to the changes in the environmental conditions. The adaptation process currently experienced in the area was reported not to be new but a process of trans- position and change which occurred through adaptation and deliverance (Hutcheon, 2006).

The analysis of several floating houses in the research location also showed the adaptation process to achieve comfort occurred in the early days of occupying the structure. This was observed from new occupants which were considered to be comfortable with the house in less than a year of residence. This is observed from their ability to adapt to the limited area in the floating house after enjoying wider space in the in-land houses which makes them conduct their activities with ease. It is important to note that the level of comfortability was assessed based on the ease with which the occupants conduct their activities in the floating house area. 


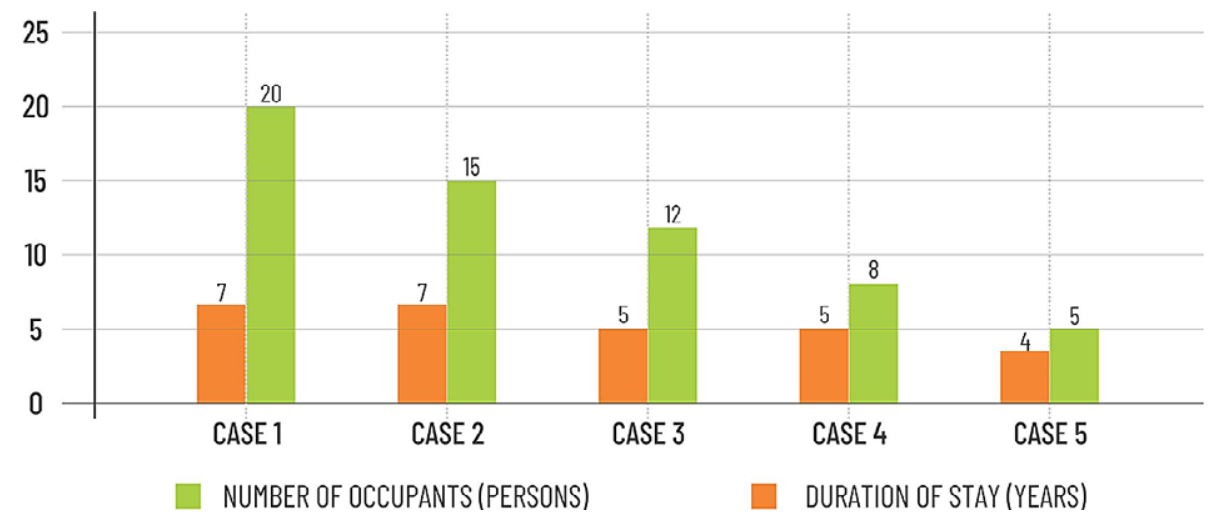

Figure 7. Number of occupants and duration of stay in Rumah Lanting

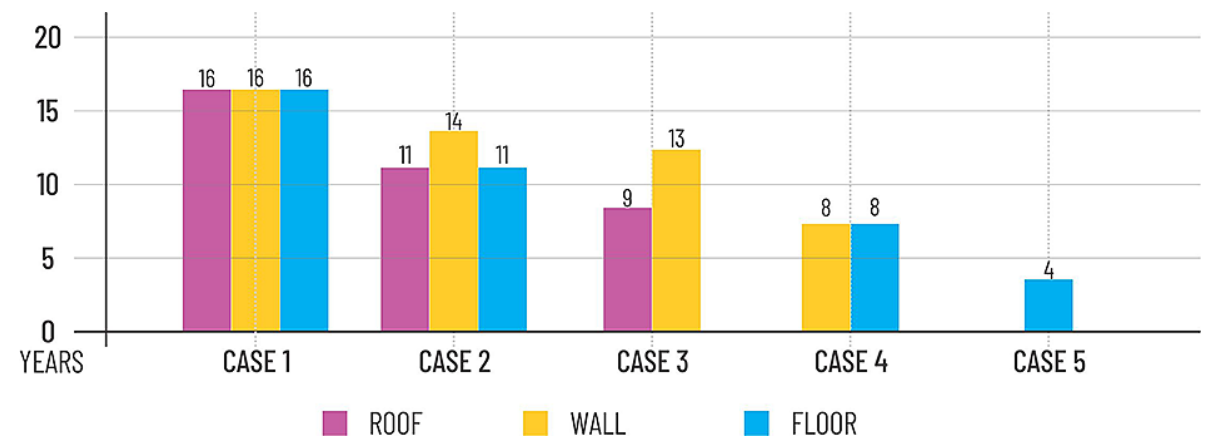

Figure 8. Part of Rumah Lanting renovation time

\section{Floating House Characteristics}

The characteristics of the floating houses were determined by analyzing the inner and outer spatial layout patterns. These patterns were created based on the behavior of occupants in arranging the spaces in line with their activities and intimate relationships as well as in relation to the physical environment. This is in line with the description of behavior patterns as a unit of the relationship between behavior and the environment (Laurens, 2004). Moreover, the occupants' experience and habits also influence the arrangement of spaces towards achieving comfort. It is also important to note that the ability of an individual to adapt to the environment differs according to their response (Rapoport, 1998).

The spatial layout in the floating house is arranged using a centralized approach and this pattern does not usually change due to the difficulties associated with maximizing the limited area. The living room is usu- ally the center area for most activities due to its status as the only public area. It is used as a multifunctional space due to the need to perform several activities in the limited space. It is, however, important to note that the same activities conducted in normal houses on the mainland are also in the floating houses such as bathing, eating, sleeping, working, playing, and several others.

The outdoor layout is also closely related to the inner space and the surrounding environment. Behavioral settings are interactions between an activity and a specific place which occur consistently according to time and situation (Haryadi \& Setiawan, 2010). Most of the floating houses are oriented towards both the land and the river and they also have a circulation route for entrance in both directions. There is also a terrace which serves as an intermediate area between the outer and inner spaces and surrounds the building to serve as an open space for the occupants.
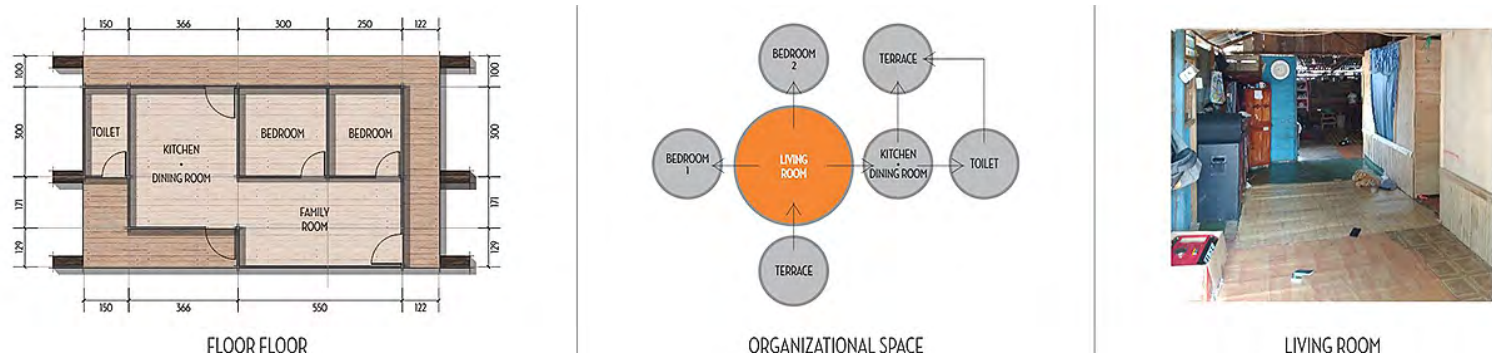

Figure 9. (a) Floor plan case 1; (b) Organizational space case 1; (c) Living room case 1 

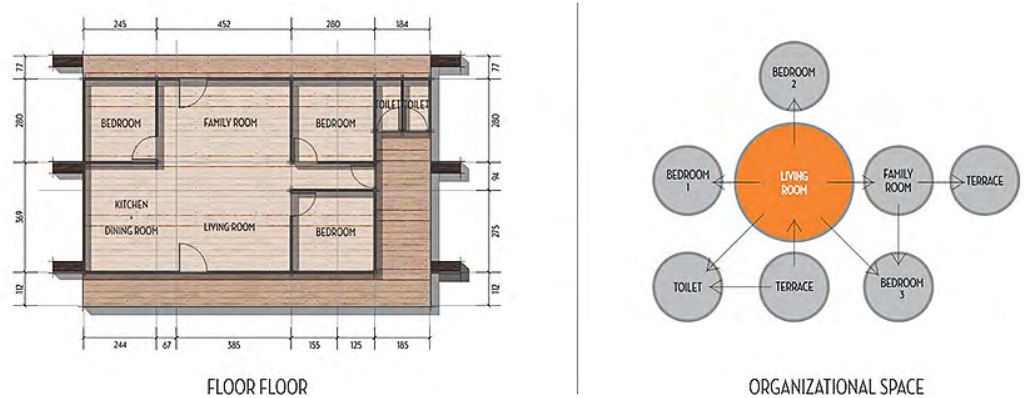

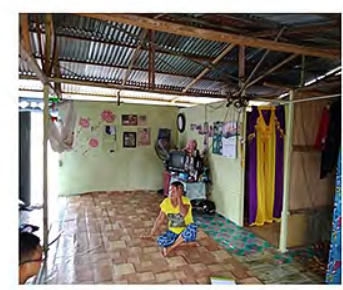

LIVING ROOM

Figure 10. (a) Floor plan case 2; (b) Organizational space case 2; (c) Living room case 2

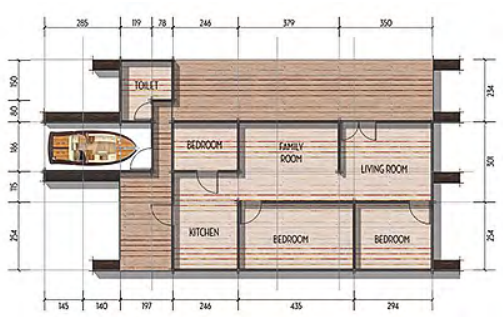

FLOORFLOOR

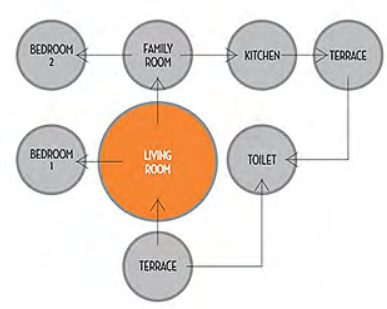

ORGANIZATIONAL SPACE

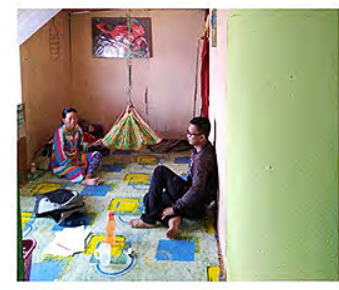

LIVING ROOM

Figure 11. (a) Floor plan case 3; (b) Organizational space case 3; (c) Living room case 3

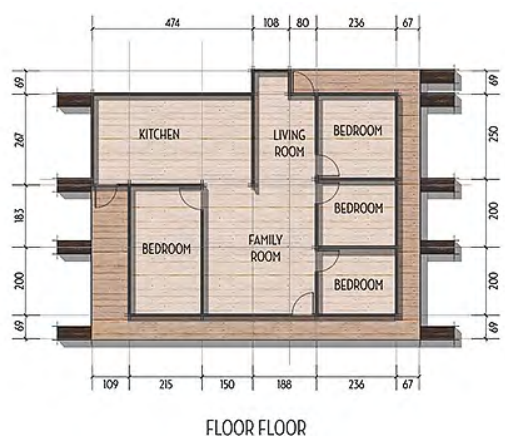

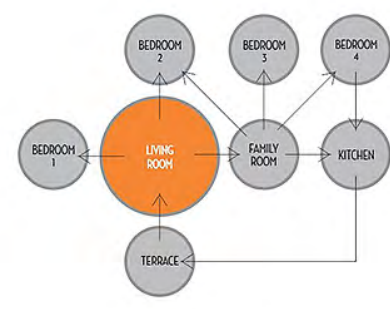

ORGANIZATIONAL SPACE

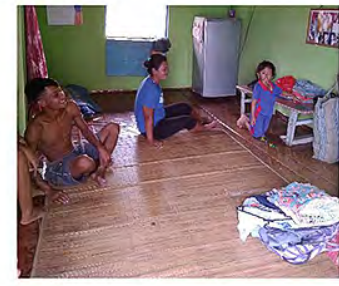

LIVING ROOM

Figure 12. (a) Floor plan case 4; (b) Organizational space case 4; (c) Living room case 4

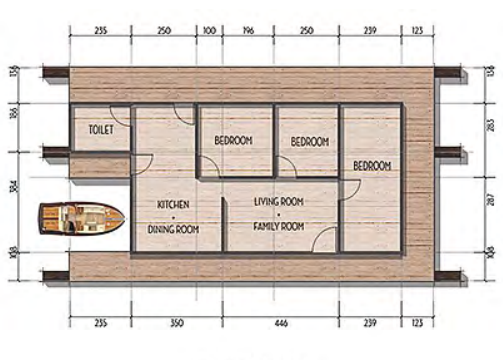

FLOORFLOOR

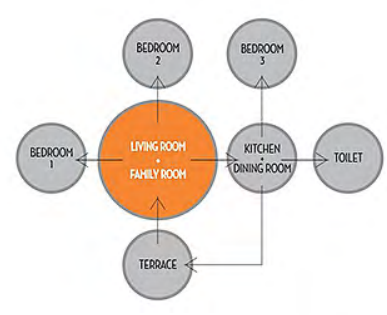

ORGANIZATIONAL SPACE

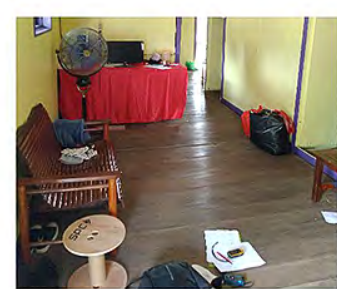

LIVING ROOM

Figure 13. (a) Floor plan case 5; (b) Organizational space case 5; (c) Living room case 5

\section{Adaptation Process}

The occupants of the floating house usually experience a drastic change in environmental conditions when the water level rises or drops and this indirectly forces the people to adapt. This means each of them can modify the building according to the climatic conditions in order to achieve comfort and safety (Roaf et al., 2009). This involves understanding the nature of the natural phenomena usually experienced (Lang, 1987) in order to individually adapt to deal with the environmental pressures. The adaptation is required to survive and ensure comfortability and it is mostly achieved through several engineering actions, improvements, or changes in different aspects of life. This process, however, occurred both actively and passively. 


\section{Active Adaptation Process}

One of the adaptation processes in the floating house is active adaptation. This involves the participation of the occupants in making adaptive actions and also emphasizes the important role of individuals in influencing the environment (Kartasapoetra, 1987). This adaptation can be allopathic and regarded as an individual active strategy in dealing with environmental changes (Gerungan, 1991). It is important to note that the environmental conditions in the study area change due to the rise and fall of water level in the Melawi river and the occupants are required to respond through a behavior that there is enough space to conduct activities both within and around the house.

The privacy of the floating house is also adjusted in the time of disaster such that the access to the buildings is controlled by occupants in normal conditions but this is limited due to the environmental conditions during floods. Meanwhile, the access can be easily visible to guests during periods of low tides, and this is known as the open limitation access type of privacy.

The activity patterns of the occupants in the $\mathrm{Ru}$ mah Lanting also change during the period of natural disasters. These activities are standard during normal conditions but the movement in space becomes more

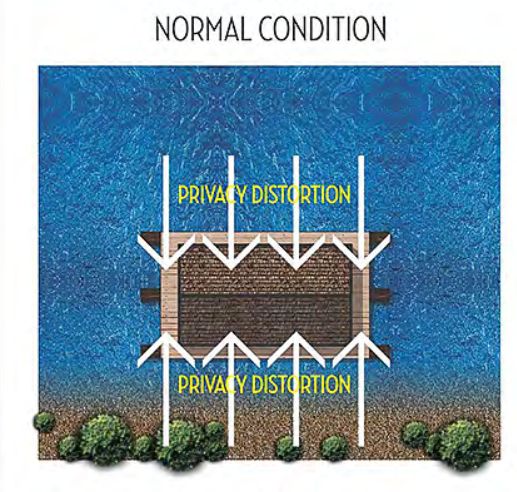

PRIVACY IS MAINTAINED

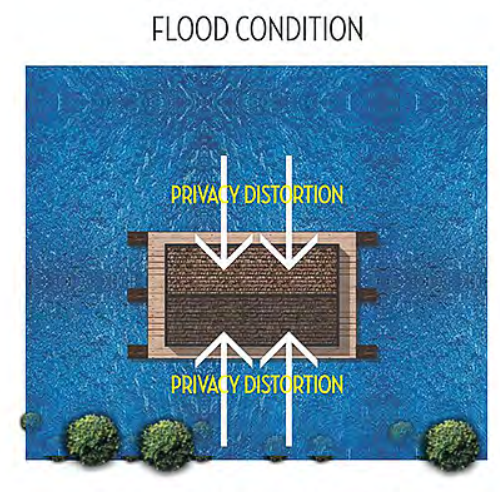

PRIVACY IS STRICTLY MAINTAINED

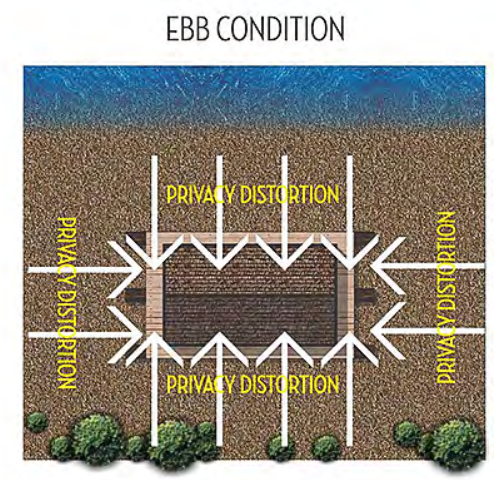

PRIVACY IS NOT MAINTAINED

Figure 14. Territory modification in floating house

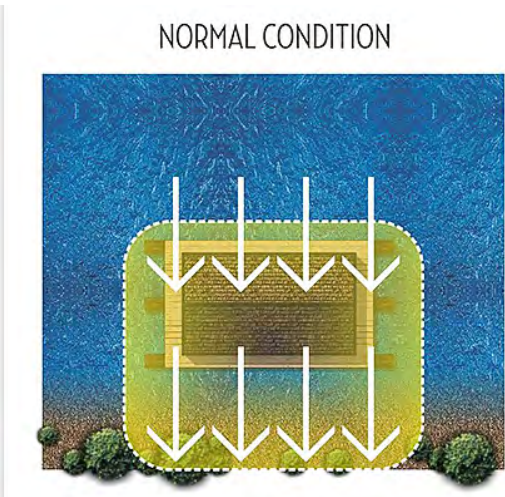

THE TERRITORY OF THE FLOATING HOUSE INCLUDES A PART THE LAND SIDE

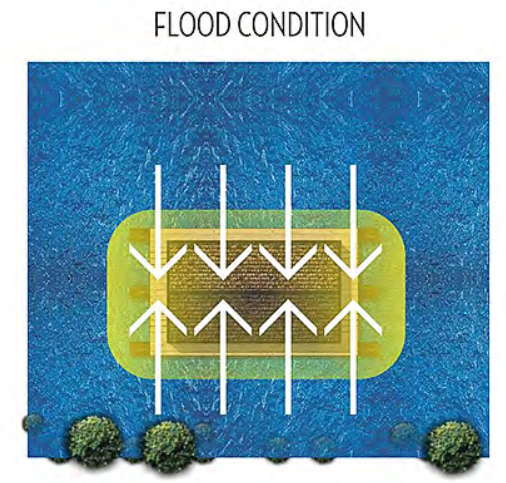

THE TERRITORY IS ONLY ON THE FLOATING HOUSE

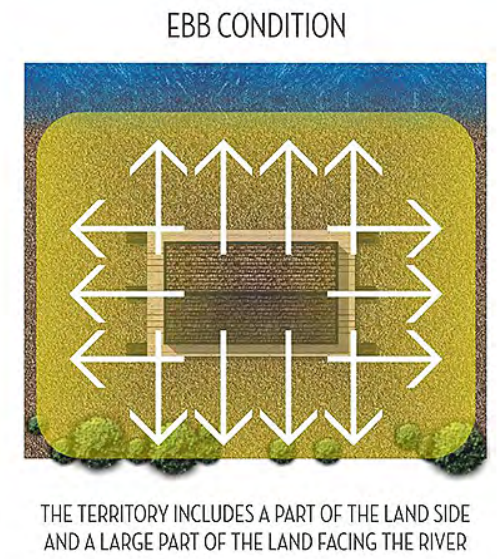

Figure 15. Privacy modification in floating house

change. Some of the activities inside the house such as bathing, playing, and interacting with neighbors are moved outside in order to adapt to the environment and this further affects territory, privacy, and activity restrictions.

The territory of the floating house is usually changed during a disaster. It is land-oriented in normal conditions but the activities towards the land are reduced during flooding and this makes the territory narrower, thereby, leading into the building. During low tide, the territory becomes wider due to the fact conservative and tends to be focused more on the inside during floods while the activity space is more expansive with the use of outdoor space during the time of low tides. These activities are similar to those usually conducted by residents living in mainland houses. Meanwhile, Rumah Lanting is a house which can be adjusted based on the activity patterns and the wishes of the occupants as well as the changes caused by natural disasters. This is observed from its elevation which is always designed to be above the surface of water and land. 


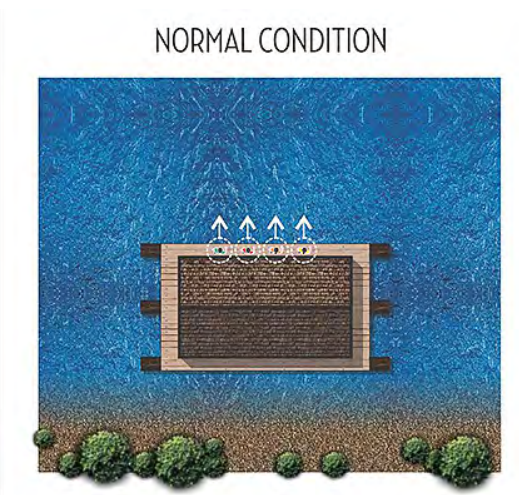

BATHING TAKES PLACE ON THE SIDE FACING THE RIVER

NORMAL CONDITION

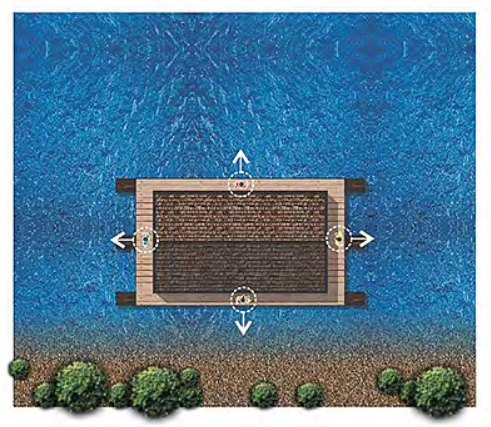

CHILDREN PLAY ON THE TERRACE OF THE HOUSE

NORMAL CONDITION

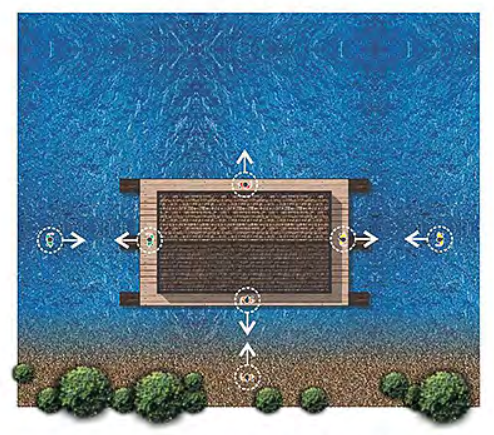

INTERACTION WITH NEIGHBORS OFTEN OCCURS

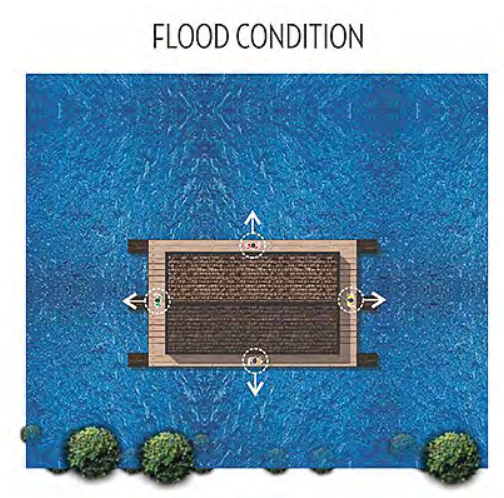

BATHING TAKES PLACE ON ALL SIDES OF THE HOUSE

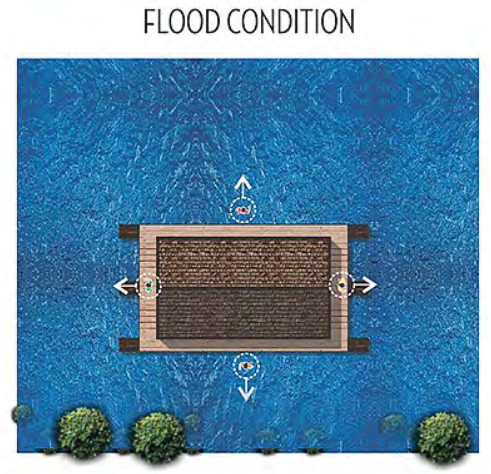

CHILDREN PLAY ON THE TERRACE AND ON THE SIDE OF INUNDATED LAND

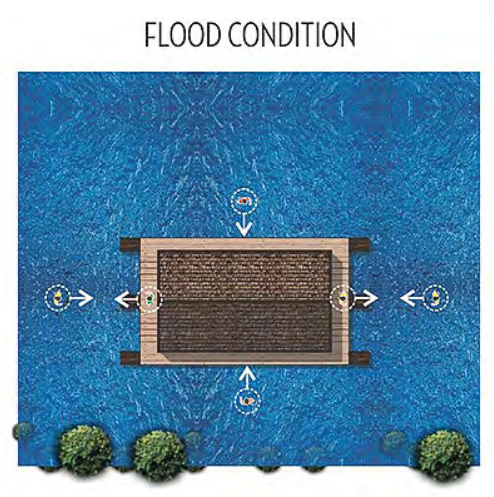

INTERACTION WITH NEIGHBORS IS RARE

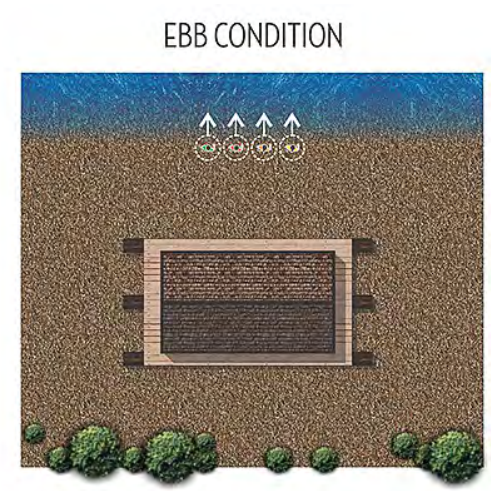

BATHING TAKES PLACE OUTSIDE THE HOUSE

EBB CONDITION

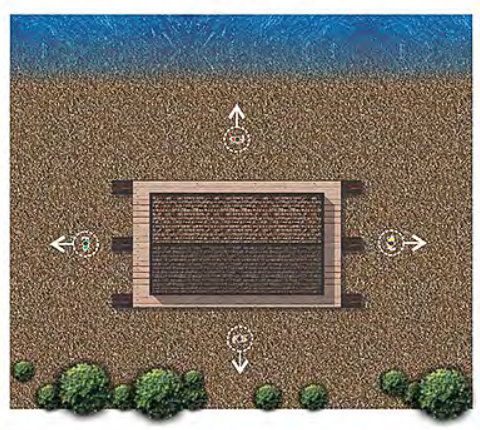

CHILDREN PLAY OUTSIDE THE HOUSE ESPECIALLY ON THE DRY RIVERBED

EBB CONDITION

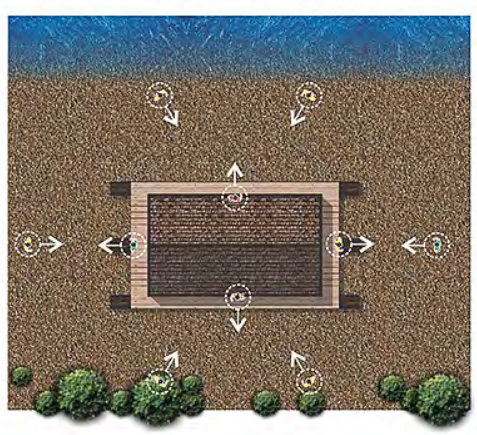

INTERACTION IS NOT ONLY WITH NEIGHBORS BUT ALSO WITH OUTSIDERS.

Figure 16. Activity pattern modification in floating house 


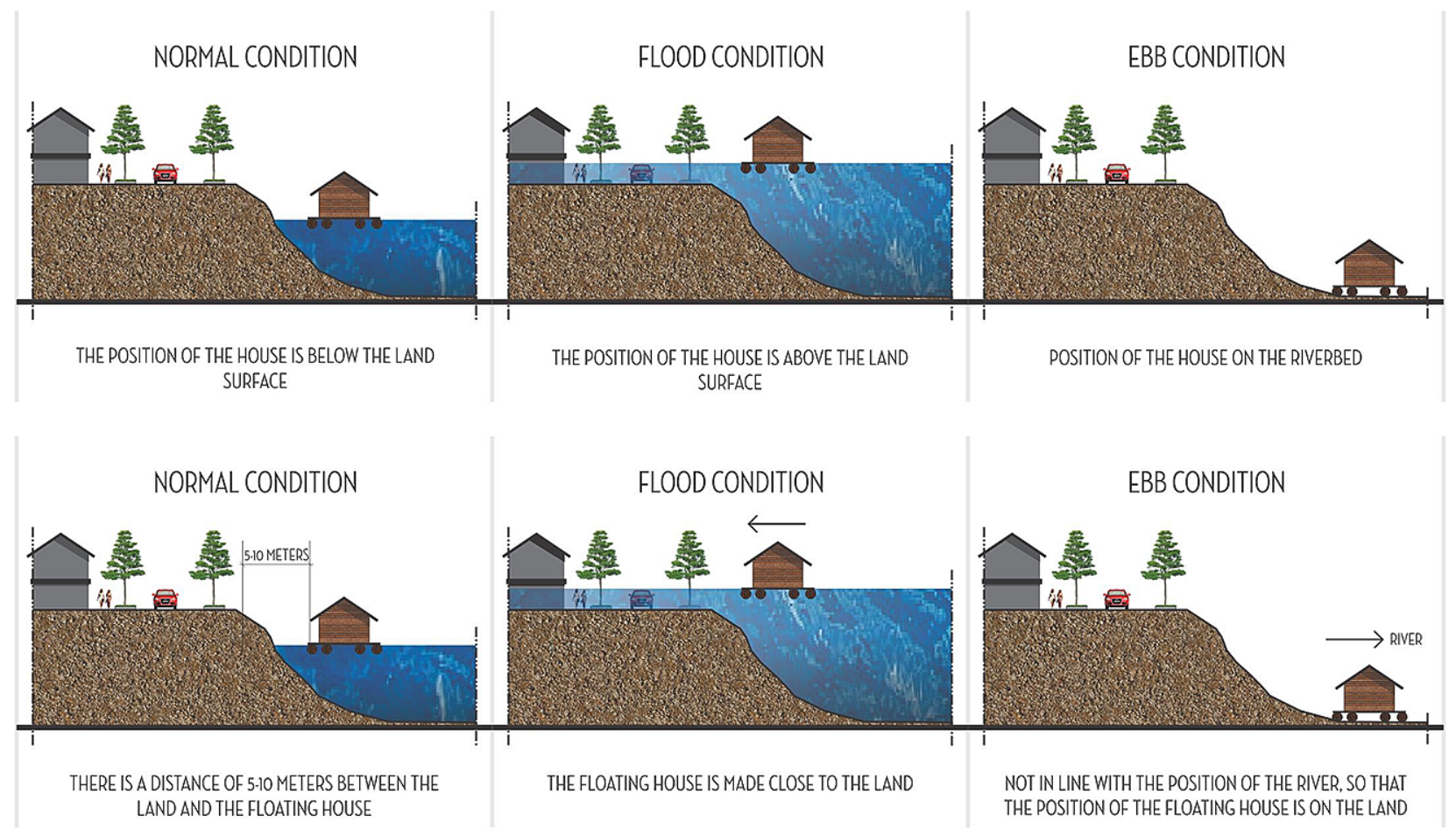

Figure 17. Position modification in floating house
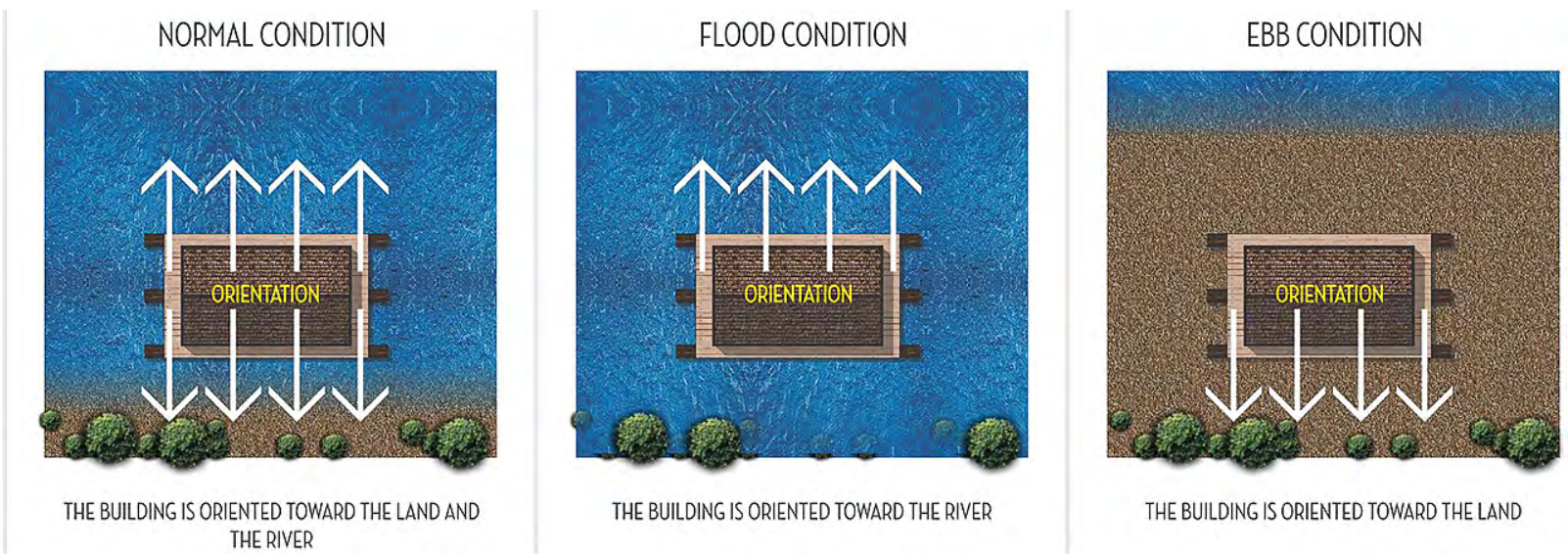

THE BUILDING IS ORIENTED TOWARD THE RIVER

THE BUILDING IS ORIENTED TOWARD THE LAND

Figure 18. Orientation modification in floating house

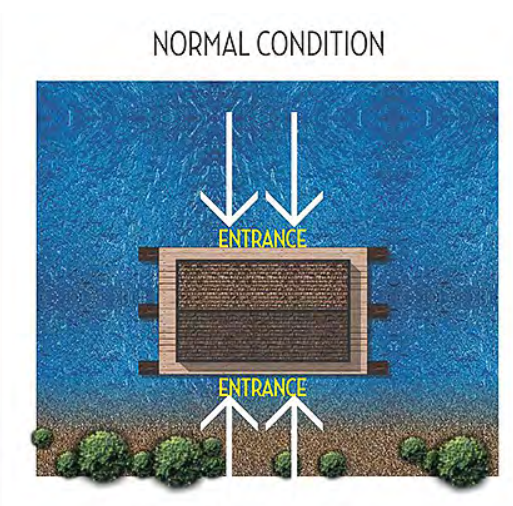

ACCESS FROM THE LAND AND THE RIVER

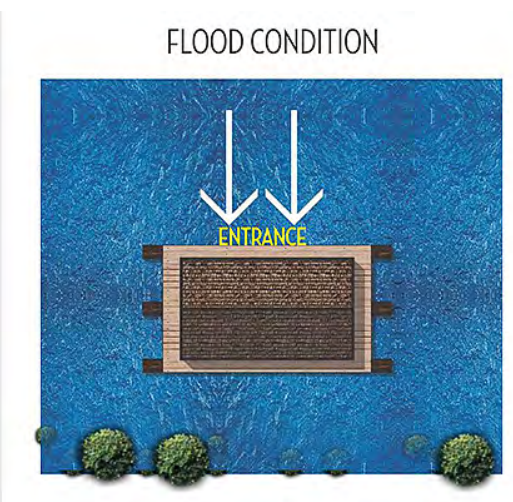

ACCESS FROM THE RIVER

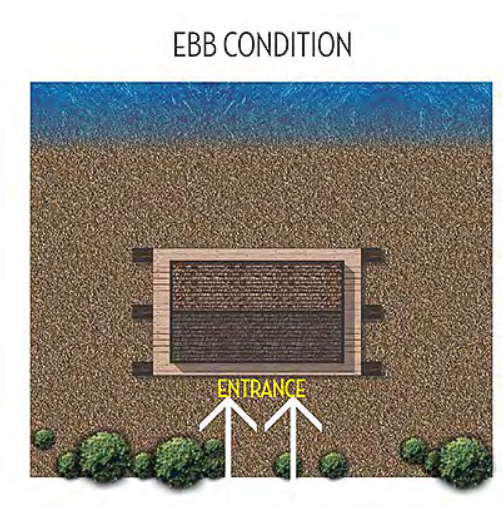

ACCESS FROM THE LAND

Figure 19. Access modification in floating house 


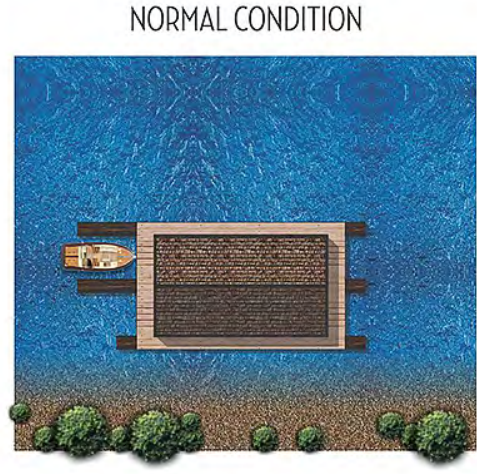

THE PIER FUNCTIONS AS A WATERCRAFT PARKING SPACE

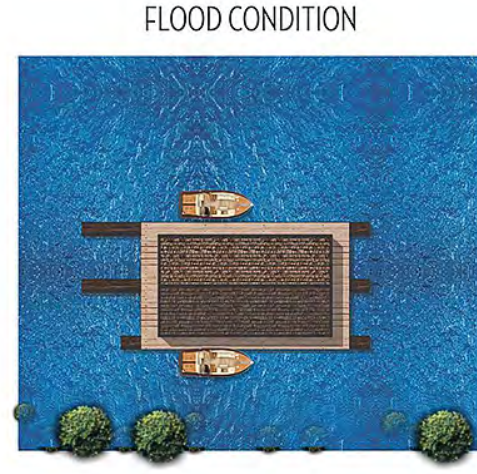

WATERCRAFT CAN BE PARKED AT THE PIER OR AT ALL SIDES OF THE BUILDING

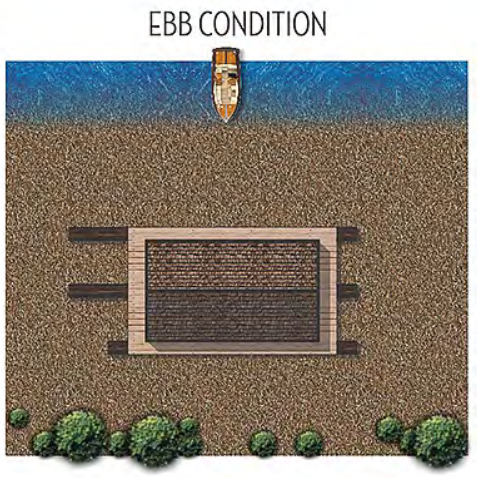

WATERCRAFT ARE NOT PARKED AT THE FLOATING HOUSE BUT ELSEWHERE

Figure 20. Function modification in floating house

\section{Conclusions}

The data and analysis obtained were used to draw the following conclusions:

1. The adaptation of the occupants was observed to be related to their period of stay in the floating house. Their focus is usually to ensure comfortability inside the house despite the changes in environmental conditions.

2. The floating house has a multi-functional space which accommodates different activities. The adjustments made to these activities do not prevent the adaptation process and the changes implemented inside the house do not significantly affect the building's physical appearance.
3. There are two main actors in the adaptations of a floating house and these include the occupants and the house. The occupants are significant to the active adaptation process while the house is the main object of the passive adaptation process.

4. Active adaptations involve the responses of the occupants towards adapting to the changes in environmental conditions with the focus on activity patterns, territory, and privacy.

5. Passive Adaptations are made by making adjustments and changes to the floating house with the focus on the position, orientation, access, and function in order to achieve comfortability.

\section{Acknowledgement}

The authors would like to express gratitude to the Universitas Tanjungpura for the support through the research fund in the 2019 grant. The authors also deliver many thanks to the department of architecture to support the development of this article.

\section{References}

Afdholy, A. R. (2017). "Rumah Lanting" arsitektur vernakular Suku Banjar yang mulai punah ["Rumah Lanting" vernacular architecture of the Banjar tribe which is starting to become extinct]. Local Wisdom: Jurnal Ilmiah Kajian Kearifan Lokal, 9(2), 103-117. https://doi.org/10.26905/lw.v9i2.1977

Chambers, R. (2006). Vulnerability, coping and policy (editorial introduction). IDS Bulletin, 37(4), 33-40. https://doi.org/10.1111/j.1759-5436.2006.tb00284.x

Clark, J. K., McChesney, R., Munroe, D. K., \& Irwin, E. G. (2009). Spatial characteristics of exurban settlement pattern in the United States. Landscape and Urban Planning, 90, 178-188. https://doi. org/10.1016/j.landurbplan.2008.11.002
Danim, S. \& Darwis. (2003). Metode penelitian kebidanan: Prosedur, kebijakan, dan etik [Midwifery research methods: Procedures, policies, and ethics]. Jakarta: Penerbit Buku Kedokteran EGC.

Daryanto, B. (2004). Rumah lanting: rumah terapung di atas air tinjauan aspek tipologi bangunan [Rumah lanting: floating house on water overview of the typological aspects of the building]. Infoteknik, 3, 1-19.

Estaji, H. (2017). A review of flexibility and adaptability in housing design. International Journal of Contemporary Architecture, 4, 37-49. https://doi. org/10.14621/tna.20170204

Gerungan, W.A. (1991). Psikologi sosial [Social psychology]. Bandung: PT Eresco. 
Gifford, R. (2012). Environmental psychology. In encyclopedia of human behavior (2nd ed.). Heidelberg: Academic Press. https://doi.org/10.1016/B978-0-12375000-6.00150-6

Gultom, B. J. \& Caesariadi, T. W. (2018). Persepsi masyarakat tepian sungai terhadap pemanfaatan ruang sirkulasi dan ruang terbuka sebagai respon mitigasi bencana berbasis bencana air di Sintang [The perception of riverbank community on utilization of circulation and open space as disaster mitigation response based on water disaster in Sintang]. Langkau Betang: Jurnal Arsitektur, 5(2), 97108. http://dx.doi.org/10.26418/lantang.v5i2.29889

Guo, S. J. (2002). Identification and resolution of work space conflicts in building construction. Journal of Construction Engineering and Management, 128, 287-295 https://doi.org/10.1061/(ASCE)07339364(2002)128:4(287)

Haryadi, \& Setiawan, B. (2010). Arsitektur, lingkungan dan perilaku: Pengantar ke teori, metodologi dan aplikasi [Architecture, environment and behavior: An introduction to theory, methodology and applications]. Jogjakarta: Gadjah Mada University Press.

Hilmanto (2010). Etnoekologi [Ethnoecology]. Bandar Lampung: Universitas Lampung.

Hutcheon, L. (2006). A theory of adaptation. New York: Routledge Taylor \& Francis Group. https:// doi.org/10.4324/9780203957721

Kartasapoetra, G. (1987). Sosiologi Umum [General Sociology]. Jakarta: Bina Aksara.

Lang, J. (1987). Creating architectural theory, the role of the behavioral sciences in environmental design. New York: Van Nostrand Reinhold Company.

Laurens, J. M. (2004). Arsitektur dan perilaku manusia [Architecture and human behavior]. Jakarta: PT Grasindo.

Marpaung, B. O. Y., \& Senders, R. (2019). The ecological influences in forming waterfront settlements in Pangururan sub-district, Samosir Regency. The 5th Friendly City International Conference: "Enhancing Culture, Community and Environment" 2019, IOP Conference Series: Earth and Environmental Science (pp 452), North Sumatera, Indonesia. https://doi.org/10.1088/1755-1315/452/1/012130

Mentayani, I. (2016). Identitas keruangan tepian sungai dan perubahannya pada permukiman vernakular di Banjarmasin [Riverbank spatial identity and its changes in vernacular settlements in Banjarmasin]. Seminar Nasional - Semesta Arsitektur Nusantara 4, (pp 17), Malang, Indonesia.

Merriam, S., \& Tisdell, E. (2016). Qualitative research a guide to design and implementation, John Wiley \& Sons.
Moleong. L.J. (2005). Metodologi penelitian kualitatif [Qualitative research methodology]. Bandung: Remaja Rosdakarya.

Mustansyir, R. (2013). Kearifan dan kendala lokal warga lanting sebagai penghuni pinggiran Sungai Sambas di Kalimantan Barat [Local wisdom and constraints of lanting residents as residents on the banks of the Sambas River in West Kalimantan]. Proceeding International Conference on Indonesian Studies 5th: Ethnicity and Globalization, (pp 261), Yogyakarta, Indonesia.

Pesurnay, A. J. (2018). Local Wisdom in a New Paradigm: Applying System Theory to the Study of Local Culture in Indonesia. International Conference on Industrial Technology for Sustainable Development (ICon-ITSD) 2017 25-26 October 2017, IOP Conference Series: Earth and Environmental Science, (pp 175). Makassar, Indonesia. https://doi. org/10.1088/1755-1315/175/1/012037

Priemus, H. (1986). Housing as a social adaptation process: A conceptual scheme. Environment and Behavior, 18, 31-52. https://doi. org/10.1177/0013916586181002

Rapoport, A. (1998). Using "culture" in housing design. Housing and society, 25(1-2). https://doi.org/10 $.1080 / 08882746.1998 .11430282$

Reinmann, A., Hutyra, L., Trlica, A., \& Olofsson, P. (2016). Assessing the global warming potential of human settlement expansion in a mesic temperate landscape from 2005 to 2050. Science of The Total Environment, 545-546. https://doi.org/10.1016/j. scitotenv.2015.12.033

Riyandari, R. (2018). "Waterfront city" mitigasi bencana banjir di Kelurahan Dendengan Luar, Kota Manado ["Waterfront city" flood disaster mitigation in Kelurahan Dendengan Luar, Manado City]. Jurnal Sains dan Teknologi Mitigasi Bencana, 13(1), 57. https://doi.org/10.29122/jstmb.v13i1.3361

Roaf, S., Crichton, D., \& Nicol, F. (2010). Chapter 7Vulnerability, Exposure and Migration. In S. Roaf, D. Crichton, \& F. Nicol (Eds.), Adapting Buildings and Cities for Climate Change (Second Edition) (pp. 134-142). Architectural Press. https://doi. org/10.1016/B978-1-85617-720-7.00007-3

Sihombing, R. \& Marisa, S. M. (2019). The role of the indigenous knowledge system of the community Dayak in water management Kahayan River: Review of local wisdom perspective. Iapa Proceedings Conference, (pp 341), Palangka Raya, Indonesia. https://doi.org/10.30589/proceedings.2018.208

Soemarwoto, O. (1991). Ekologi, lingkungan hidup, dan pembangunan [Ecology, environment and development]. Jakarta: Penerbit Djambatan.

Sugiyono. (2012). Statistik untuk pendidikan [Statistics for education]. Bandung: Alfabeta. 